\title{
Brothers from Different Mothers-Confucius, Benedict, and Francis: The Historical Search for Humane Leadership
}

\author{
Cheryl Crozier Garcia ${ }^{1,2}$ \\ ${ }^{1}$ MAHRM Program, Hawaii Pacific University, Honolulu, USA \\ ${ }^{2}$ Contributing Faculty, MHRM Program, Walden University, Minneapolis, USA \\ Email: ccrozier@hpu.edu
}

Received May 10, 2013; revised June 30, 2013; accepted July 10, 2013

Copyright (C) 2013 Cheryl Crozier Garcia. This is an open access article distributed under the Creative Commons Attribution License, which permits unrestricted use, distribution, and reproduction in any medium, provided the original work is properly cited.

\begin{abstract}
Ongoing global economic downturn, social and political upheavals, revolutionary changes in technology, and frightening climate change are having massive impacts on the ways people live and work. This paper examines the teachings of 3 of these leaders: Confucius, Benedict of Nursia, and Francis of Assisi, whose teachings may inform the ways in which today's leaders motivate a workforce and deal with uncertainty. Though separated by both time and culture, these 3 men shared common biographical traits that informed their teachings and shaped their ideas about appropriate behaviors for leaders and their subordinates. Compassion, sincerity, wisdom, and trust are traits that all 3 stress as vital for leaders trying to accomplish meaningful goals in the face of adversity.
\end{abstract}

Keywords: Leadership; Servant Leadership; Transformational Leadership; Ethics; Morality; Confucius; Benedict of Nursia; Francis of Assisi; Ethical Leadership

\section{Introduction}

The second decade of the $21^{\text {st }}$ Century is being called a time of unprecedented change. The ongoing global economic downturn, social and political upheavals, revolutionary changes in technology, and frightening climate change are having massive impacts on the ways people live and work. Extremely high level of stress on the job is creating a work environment that can bring out the worst in people. Workers feel trapped in oppressive jobs where their contributions are not valued. Managers feel pushed to increase productivity with fewer resources. Layoffs, furloughs, and the loss of traditional employee benefits create feelings of frustration and hopelessness in wage earners at all organizational levels. The manageremployee relationship is being strained as each tries to meet both performance imperatives and personal needs. With few outlets for their frustration, people sometimes indulge in poor behavior, treating one another rudely, disrespectfully, and even abusively. Workplace bullying is becoming a serious problem in some companies [1-4].

One response to this upsurge in workplace hostility has been a call for a return to civility and a reminder to "play nicely with one another". Broadcast media and bookstores are full of advice about responding courteously to people who are unmannerly or downright mean. These sources suggest calmly asserting one's needs and being equally calm and assertive when calling unacceptable behavior to the bad actor's attention. Still, poor behavior continues to thrive.

People seem to think that this is a new phenomenon. However, there have been other times in history when rapid change leads to less than mature behavior. In those times, people looked to their leaders to set the example of noble behavior in the face of uncertainty - and many of those people were disappointed in what they saw of their leaders' behavior. There are, however, some examples of leaders who have chosen to take the moral high road during times of strife, advocating unselfish, compassionate leadership behaviors, and exhorting their followers to do likewise. These leaders' counter-cultural approaches to leadership stress self-awareness, self-restraint, lifelong learning, and putting the needs of the group ahead of individual profit. This paper examines the teachings of 3 of these leaders: Confucius, Benedict of Nursia, and Francis of Assisi. Like today's leaders, they lived through times of unprecedented change; yet they man- 
aged to set examples of compassion, personal honor, and humane leadership that continued to inspire those who believed that the best leadership was leadership by example for the benefit of all.

\section{Leadership’s Current Conceptual Context}

The relationship between leadership and organization survival is undergoing close examination. Current literature focuses on the relational aspects of both. There is an increasing emphasis on ethical, servant, and transformational leadership, in which those in leadership positions are expected to embrace a broader definition of stakeholders and a longer-term orientation in assessing organizational success. The most current literature on leadership categorizes leaders in 3 ways:

- Ethical leaders, who “encourage normative behavior and discourage unethical behavior" [3];

- Servant leaders, who "emphasize[s] service to others and recognition that the role of organizations is to create people who can create a better tomorrow" [5] and;

- Transformational leaders, who "commit[s] people to action, who convert[s] followers into leaders, and who may convert leaders into agents of change [6].

Regardless of its label, each type of leader shares several common traits. They set the tone for subordinate behavior, apply what they have learned through education and experience to current challenges, and embed expectations and assumptions about acceptable work performance into organizational systems. Leaders are also expected to recognize and reward organization performance that meets or exceeds expectations and correct the substandard performance of people and systems. Trait, behavior, and contingency approaches to managing people and resources are part of the leader's arsenal as are "dynamic delegation" [7] and building connectivity between employees and the information they need to succeed. This facilitation activity transcends mere encouragement and compels leaders to take an active role in the professional development of their superiors, subordinates, and peers. In short, leaders play a critical role in shaping the ethical behavior of individual organization members as well as the organization's collective citizenship behavior [1,3,8-10].

Ethical, servant, and transformational leadership models all rely upon the same behavioral assumptions, which are articulated by Al-Sharafi and Rajiani [8] as having a mitigating effect on an organization's citizenship behavior.

- Altruism, defined as employees helping one another with job-relevant tasks.

- Civic virtue, defined as employees playing an active role in organization governance.
- Conscientiousness, defined as going beyond the normal requirements or expectations of the job.

- Courtesy, defined as politeness, respect, and consideration for others.

- Sportsmanship, defined as employees exhibiting a positive attitude and willingness to tolerate challenges in the work environment [8].

Through the individual and organizational manifestation of these core citizenship behaviors, leaders optimize stakeholder interests and fulfill the ethical duties of leadership [6].

Leadership should not be viewed as a set of essential job functions or as a position within an organization's chain of command. Rather, leadership is a social process in which people at various levels in an organization work together to meet their own needs and the organization's goals. In fact, within any organization, those in formal leadership may not be the only individuals to whom leadership authority is imputed. Informal leaders also have the power to motivate the group to meet shared expectations. Both formal and informal leaders are those who can personalize interactions with team members, providing the coaching and mentoring each might need to become a more valuable member of the organization. This requires a change in leader focus-moving away from a traditional leader-follower relationship construct to a leader-stakeholder approach based on ethically congruent relationships between equals playing different roles within the organization. Ultimately, it is the perception of a person's past success and everyday interaction between organization members that mark a person as a leader, whether they hold a leadership position or not [7-12].

Current leadership challenges. Ethical, servant, and transformational approaches are not always successful. There are a number of reasons for this. First, leaders are widely distrusted. Caldwell, Dixon, Floyd, Chaudoin, Post, and Cheokas' (2012) study found that only 7\% of employees believed that senior management's words and actions were congruent; only $25 \%$ of employees trusted management to make good decisions in times of uncertainty [6]. Second, while broad rhetoric makes an inspiring vision, it is often difficult to turn a grand message into reality. Third, there is often an incorrect assumption made that there is a pre-agreement of terms. Leaders and subordinates may not have a shared understanding of what is expected or how to achieve the stated, but poorly understood goal $[1,9,15]$.

Fourth, even a highly trusted leader with a well-understood message faces the challenges of a mixed reality. Geographically dispersed and multi-cultural groups are difficult to manage. The combination of face-to-face and technology-assisted communication makes for spotty understanding even when all parties agree on the definition of terms. Successful, cohesive groups in which there is a 
high degree of norming may have a lower probability of success than less tightly bonded groups. Overly normed groups may oppress individual voice, thereby hindering progress. Additionally, lack of prosocial contact between the team and their beneficiaries may de-motivate team members before the goal is reached $[6,7,9,16,17]$.

Finally, the traits necessary to successfully practice ethical, servant, or transformational leadership are difficult to develop but essential to the successful implementation of any of the 3 models. An intrinsic desire to behave ethically is a core component of successful leadership performance, but is not enough on its own. Ethical, servant, and transformational leaders are perceived as fair and trustworthy. They are able to clearly articulate their own understanding of what is right and wrong, and self-circumscribe their behavior accordingly. They demonstrate their leadership style by their movement through the world, not just through the workplace. These leaders view leadership as "a way of life rather than a management technique” [5]. They have a strong commitment to change that benefits all stakeholders, challenging the status quo when necessary and taking action when they have the power to do so. Ethical, servant, and transactional leaders embrace spirituality, morality, positivity, and community, working to engender all 4 in the organization for its own improvement and the betterment of society. Empathy, self-awareness, and a commitment to serving others are characteristics of the ethical, servant, or transformational leader [1,3-5,7,12-18].

Overcoming the challenges to ethical, servant, and transformational leadership. What seems clear in the current literature is that value-laden terms are not defined in any coherent way. The literature stresses that ethical, servant, and transformational leaders behave in ethically appropriate ways, but then fail to say which behaviors are ethically correct and which are not. The definition of morality and words like good, bad, right, and wrong are assumed to be universal, hard-wired into every culture, and agreed upon by every individual. This is not simply true. Standards of ethical conduct vary across cultures and sub-cultures. Neither leaders nor followers should expect that either will know what behaviors are ethically correct without being told. An organization's leaders must articulate the organization's values, define them clearly, communicate them widely, and then model those values in their relationships with all the organization's stakeholders. Leaders should also allow their employees to see the positive prosocial impact that their pre-defined ethical behavior has on beneficiaries of the organization's actions [1,3,5,6,8,9,11,13-17].

There are examples in history to which today's leaders might look for examples of articulating, communicating, and modeling ethical behavior. These leaders' innovations have withstood the test of time, crossed both geo- political and cultural boundaries, and been embraced by countless people throughout history seeking to live a more inclusive, caring, and selfless life. Confucius, Benedict of Nursia, and Francis of Assisi continue to be viewed by those who know their teachings as renowned advocates for building communities which serve the best interests of all their members, which care for the natural environment, and set high standards for neighborliness, civility, and charity.

\section{The Men and Their Times}

\subsection{Confucius (c. 551-479 BCE)}

Confucius lived during China's Zhou (Chou) Dynasty (1100-256 BCE). His lifetime was particularly characterized by a breakdown of the traditional feudal system, social upheaval, and significant economic change. As a member of the literate aristocracy, Confucius should have been eligible for high-ranking bureaucratic positions. However, his family was poor and lacked the necessary social connections to qualify Confucius for an important post. He held a number of minor civil service positions, but when it became apparent to him that he would never be promoted to the level for which he believed himself qualified, he became disillusioned and resigned his position. Confucius then became an itinerant scholar and teacher, but this was usually insufficient to afford him a comfortable living. Confucius experienced significant economic hardships, was sometimes reduced to mendicancy, and was jailed at least once. Eventually, Confucius attracted the attention of some feudal lords who called upon him for advice, though few put his counsel into action. He also attracted numerous followers. His disciples documented his teachings and eventually compiled them into 20 books of aphoristic sayings. Today, these collected teachings are called The Analects. They have been translated into many languages and have earned Confucius a reputation as one of the greatest sages and teachers of all time-a reputation he was denied in his lifetime [19-29].

Confucian teaching. Confucian teaching is not a religion-there is no deity figure. Confucianism is a social philosophy whose goal is to achieve harmony through appropriate ethical behavior in one's roles and relationships. Individual identity is defined entirely in terms of one's status in the community. The most important social unit in the community is the family [24,30].

Confucius articulated a relational network in which that selflessness and morally upright behavior are characteristics of a good leader. Confucius refers to those who have attained this level of personal development as Humane, and in the Analects he defines the traits of a Humane leader and explains why they are important to the leader's ability to lead. 
There are five essentials. If you can put them into practice throughout all beneath Heaven, then you've mastered Humanity. They are reverence, broad-mindedness, sincerity, diligence, and generosity. Reverent, and so never scorned; broad-minded, and so winning over the people; sincere, and so trusted; diligence, and so accomplishing much; generous, and so served willingly (Analects XVII:6).

Developing Humanity. Becoming Humane is not an accident. Confucius believed that those seeking to develop their own Humanity should dedicate themselves to education and self-cultivation. The kind of education Confucius advocated might be compared favorably to a modern liberal arts curriculum that includes history, music, literature (especially poetry), religion, culture, and government. Education was not intended to simply gather new knowledge. On the contrary, education was the portal through which a person attained Humanity. Confucius believed that the educated person would realize that selfishness and dissolute behavior was counter to the common good, and would amend his or her behavior accordingly. Only careful attention to duty in one's social roles could create and sustain peace and harmony. In addition to education and a commitment to lifelong learning, Confucius advises the following traits to help activate Humanity in the person's life: filial piety, strong work ethic, respect for tradition, and obedience to one's superiors [19-30].

\subsection{Benedict of Nursia (c. 480-547 CE)}

Benedict was born and lived during the waning days of the Roman Empire. This time and place was distinguished by a deteriorating economy and physical infrastructure, barbarian invasions of Rome, and immoral behavior. Benedict was a twin and the son of a wealthy Italian family. He received the liberal education commensurate with his wealth and rank; his education included the study of Aristotle, Plato, and Socrates [31,32]. Benedict was sent to Rome to study law, but became disgusted and disillusioned by the licentious behavior he observed there. Benedict abandoned his studies, left Rome, and became a hermit at Subiaco. He attracted both followers and critics. His followers became so numerous that he established twelve monasteries in Subiaco. Benedict's critics were so threatened by his teachings and his example that two different assassination attempts were made against him —one by monks who had invited him to lead them, and another by a local priest. Benedict survived both attempts on his life, and, with several handpicked followers, founded a new community at Monte Cassino. It was at Monte Cassino that Benedict wrote his Rule. [32] While it was intended for only the monastery at Monte Cassino, it has survived into the present and is used by most Western Christian monasteries [33-42].
Benedictine teaching. Benedictine teaching is not the basis for a religion. It is deeply rooted in $6^{\text {th }}$ Century Western Christianity, and was intended to instruct Benedict's followers on how to live a deeply spiritual life. Benedict intends his monks to live in community with others and under obedience to an abbot or abbess ${ }^{1}$. In the Rule, Benedict spends a great deal of time explaining the relationships within the monastic community and the behavioral expectations within those relationships. All exhortations in the Rule are intended to build a strong community in which all are able to use their strengths, overcome their weaknesses, and work for the good of all. Deference to the needs of others is the mortar that builds the community; humility is the social lubricant that sustains it [33-42].

Building community. While Benedict intended all members of the monastic community to work diligently for the community's good, that work is not only outwardly focused. Each monastic must also focus on his or her own personal and intellectual development. Benedictine humility begins with a strong sense of self. Specifically, all members of the community must dedicate themselves to using their strengths and overcoming their weaknesses for the community's good. Each must be more concerned for the well-being of his or her confreres than for his or her own desires. Casey writes, "true community is built in self-denial $\cdots$ it is the means by which each person builds up the ambience of the community” [35]. Thus, building a true Benedictine sense of community requires each individual to develop the following traits: community loyalty, strong work ethic, adherence to the accepted standards of behavior, and obedience to superiors, peers, and subordinates [33-42].

\subsection{Francis of Assisi (c. 1182-1226 CE)}

Francis is the author of the Prayer of St. Francis, also called the Peace Prayer, and the Canticle of the Sun, as well as an organizational constitution that has been in use for more than 800 years. Francis was born during a time of significant social, economic, and political change marked by a rising middle class, the shift toward a currency-based economy, and constant wars between rival city-states. Francis was the son of an affluent family. His father was a merchant who took Francis with him on buying trips to France. Francis is reputed to have been an easygoing student who preferred socializing with friends to study. However, Francis did receive an education suitable to a young man of his station, studying literature, religion, history, music, mathematics, astronomy, rhetoric, and languages [43]. He excelled at music and poetry and earned some distinction as a singer and musician.

\footnotetext{
${ }^{1}$ Benedictine women's communities in the United States are led by a prioress. Her duties are identical to those of an abbot or abbess, only the title is different.
} 
The early teaching of his mother, who was French, and his time in France with his father, exposed Francis to the troubadour tradition with its concept of chivalric love. As a result, Francis developed an especially charming, wellmannered, and deferential style $[43,44]$. This gentlemanly demeanor informed Francis' later work with the poor and the sick [44-53].

Francis' father expected young Francis to take over the family textile business. Francis, however, became a soldier. Francis was captured and held as a prisoner of war; during that time, he ministered to his fellow prisoners, working to keep their morale high. After his release, Francis suffered a serious illness, but after his recovery, returned to work in his father's shop. Francis became aware of the social and economic injustice around him, particularly the suffering of the poor and people living with leprosy (Hansen's disease). He grew highly dissatisfied with the growing worldliness, political strife, and immoral behavior of his peers, and the increasing disenfranchisement of the poor [54]. Francis rebelled against the deterioration of fundamental moral values by giving large sums of money, food, and clothing to the less fortunate. His sincerity and selflessness attracted other disillusioned men and women to join his work of caring for the poor and the sick. This small community vowed obedience to the Gospels, poverty, and chastity. They supported themselves through manual labor and, when necessary, begged for their food and other needed supplies. Whatever resources they had were shared by all. They cared for the sick, especially those living with leprosy, and worked alongside the poor laborers to whom they ministered and preached [44-53].

Franciscan teaching. Franciscanism is not a religion in itself; it is more accurate to view Franciscanism as a social philosophy that seeks to build a peaceful world through self-awareness, selfless behavior, respect for the physical world, fraternal love, and service to others. In Franciscan teaching, the family is the basic unit of society, but this family is not created solely by blood or marriage. Membership in the family is extended equally to people, animals, and the forces of nature, and all family members are equally expected to work for the universal common good of the family and to bring about peace. Even death is welcomed as a sister who embraces all with equal love [44-53,55,56].

Developing Peacemakers. Peacemaking is the ultimate goal of Francis' teaching; it is intentional, and it is hard work. Peacemaking is seen within Francis' worldview as a process to which Franciscans are expected to commit and re-commit daily. While peace can be attained, it cannot be maintained unless all are committed to sustaining it. In the Peace Prayer, [56] Francis articulates peace as the replacement of negative emotion with positive action; the peacemaker is a conduit through which those in need receive healing and succor. The peacemaker acknowledges his or her own needs, but intentionally defers to the needs of others. Through this deference, peacemaking is a redemptive act for both the giver and the receiver, and becomes a circular process of relationship building: each person works to meet another's needs, and ultimately, all needs are met. Francis identifies specific traits as critical to the developing one's abilities as a peacemaker: family loyalty, self-awareness and self-renunciation, deference to the needs of others, and obedience to one's superiors and the laws of nature $[43-53,56]$.

\section{Benedict and Francis Explain Confucius' Humane Leadership}

As stated earlier, Confucius identified 5 traits of the humane leader: reverence, broad-mindedness, sincerity, diligence, and generosity. Benedict and Francis define these traits in their respective Rules. An examination of these traits using the Benedictine and Franciscan Rules helps to review Confucius' teaching from a Western Christian point of view.

Reverent, and so never scorned. Confucius recognizes the innate worth of each individual, and believes that this should be honored. Within Benedict's [57] and Francis' [58] Rules, a reverent attitude is the standard, not only in human relationships, but also extended to animals, property, and the natural world. In relationships between Benedictines or Franciscans and their confreres, reverence activates the divine spirit present in both. It is not enough to respect people for what they have or what they can do. People must be respected simply because they exist. While individuals may be valued for their talents or accomplishments, those with fewer talents and abilities are equally entitled to respect and to be treated with basic human dignity. The simplest way to earn respect is to treat others respectfully [56-58]. Animals and the natural world also possess the divine spark and are revered accordingly, and the community's tools and other property should be treated as sacred vessels of the altar $[55,57]$.

Inattention to the needs of others, failure to care for the community's property, and wastefulness are contrary to the appropriate attitude of reverence. Like Confucius, Benedict and Francis expect that the leader's reverent behavior will engender similar behavior in subordinates, leading to respectful treatment for all by all. Reverence by example helps to create and maintain the community's appropriate other-centeredness, so that each community member can be encouraged to, and rewarded for, working for the good of all.

Broad-minded, and so winning over the people. Confucius understands that people dislike being judged, and that people will not admit their mistakes or seek help if they think they will be criticized for doing so. Benedict 
and Francis also understand this, so they encourage all community members not to judge others or criticize harshly when mistakes are made. When consequences are meted out, they should be developmental, not punitive.

Leaders, too, are expected to disclose their own mistakes and to ask pardon of the community for lapses in judgment. When leaders are forthcoming about their mistakes, the community is advised to forgive and remember that all are equally flawed and equally deserving of a second chance. Harsh criticism and punishment do nothing to preserve community harmony. [56-58]

Sincere, and so trusted. Confucius knows that leaders must earn the trust of their followers. Benedict and Francis also acknowledge the importance of mutual trust between leaders and followers, and state that leaders must earn the trust of their followers even before they assume positions of authority. They can do this by exhibiting the traits of humane leadership before they assume office in their daily interactions with the community. Leaders are expected to say what they mean, and then back their words with action-this exemplifies Benedict's and Francis' definition of sincerity in a leader. Sincerity is proven when the leader leads by example, sharing equally in the community's work, fun, and hardships.

Because Benedictine and Franciscan teaching stress an egalitarian leadership model, sincerity within either a Benedictine or a Franciscan community is exhibited through servant leadership. The leader must be seen to consistently put the community's needs ahead of those of any single community member. This may mean sacrifice on the leader's part, but the truly Benedictine or Franciscan leader understands that duty comes with power. Good Benedictine and Franciscan leaders are willing to follow that duty, even when it means foregoing their own needs or desires [56-58].

Diligent, and so accomplishing much. Confucius realizes that most people dislike having their leader stand idly by, watching them work. Benedict and Francis are likewise critical of leaders who do not participate in the community's labors. Hard work and dedication are essential parts of the Benedictine or Franciscan leader's role. The leader is expected to set an example for diligence that the community can follow. While diligence in manual labor is important, the leader is also expected to set an example for diligence in service to the community, in frugality when using the community's resources, in humility, and in offering hospitality to guests [55-58].

Generous, and so served willingly. Confucius believes that people will give when others give to them. While generosity means that one is willing to give freely to others, the term takes on quite a different meaning in the Benedictine and Franciscan milieux. Both Benedict and Francis teach that private ownership is contrary to main- taining the community's peace and good order. Ownership of an item does nothing to increase its utility. Both Rules expressly forbid private ownership, so the first step in generosity is to renounce one's own personal possessions and learn how to share the community's tools and other resources so that each community member's needs can be met. Once the renunciation of private property has occurred, the leader can establish an environment where true generosity can prosper. True generosity in Benedictine and Franciscan teaching is generosity of spirit ${ }^{2}$. This is manifested by the leader's willingness to be emotionally present to the community, to allow the community to see the leader's flaws and fears, and to allow each community member to play as full a role as they are able in the community's life and work, joining together in deeper levels of spiritual intimacy [56-58].

\section{Conclusions}

While some of us living in the early $21^{\text {st }}$ Century may believe we are facing unprecedented problems, the reality is that every generation believes itself challenged in novel ways. Economic challenges, political strife, war, and changing social values are common to every generation. Likewise, uncaring leadership, nepotism, abuses of power, and licentiousness are common to every human era-somehow, mankind manages to survive. Each generation has rebels who call for peaceful resistance to negative behavior. They see the potential of the people around them, and exhort people to be their best and strive to maximize their potential. These rebels are ridiculed by some, but embraced by others. Sometimes, their countercultural ideas survive to benefit subsequent generations of people who seek answers to society's ills.

Confucius, Benedict, and Francis were 3 such leaders. They came from different cultures and different eras, but they shared a common vision, that people working together and respecting each other could change their communities for the better. These 3 teachers also had similar ideas about how positive change germinated and grew in society. It was these countercultural ideas that attracted their followers and their detractors, and helped Confucius', Benedict's, and Francis' teachings survive across centuries, earning them reputations for wisdom and compassion. These ideas might be adopted successfully in any era by people who are dissatisfied with the status quo and want a better life for themselves and their neighbors. Practicing the humane leadership Confucius defines from and Eastern perspective, and Benedict and Francis further articulate through the lens of Western Christian monasticism, requires the leader to develop and constantly refine the following traits.

Self-awareness and lifelong commitment to community.

\footnotetext{
${ }^{2}$ See Matthew 5:3-12 [59].
} 
Confucius taught that change started within the individual. A person must first be able to envision and articulate the kind of community in which he or she would like to live. Then the person must be willing to work to bring that community to life. Self-awareness would require the person to identify his or her strengths that might be used to bring about change, as well as individual weaknesses that would impede change. The person must be willing to work for the good of the community in all things, even when doing so means foregoing one's own desires. Benedict and Francis share that belief; their respective Rules are written for people who are interested in learning more about themselves by living and working well with others. Both Benedict and Francis require their followers to commit to ongoing self-reflection, self-disclosure, and commitment to the good of the community and to those less fortunate.

Willingness to operationalize humanity in one's personal relationships. Confucius recognized that change in society required change in interpersonal relationships; Benedict and Francis articulated specific codes of behavior for their followers. The individual must work to ensure that his or her relationships reflect mutual respect, mutual dignity, and compassion. Within the relationship, each person must strive to behave honestly and amiably, treating the other as they wish to be treated. Selfishness, backbiting, and one-upmanship are contrary to the maintenance of humane relationships. When the individual is treated unjustly, it is not conducive to a humane relationship to respond in kind. Instead, the individual may choose to ignore the disrespectful behavior and continue to behave courteously to the other. Alternatively, the individual may choose to practice fraternal correction, gently explaining to the confrere how the individual would prefer to be treated. If the disrespectful behavior continues or worsens, the individual is justified in discontinuing the relationship and seeking out new, like-minded comrades.

Appreciation and support for the natural environment. According to Confucius, a humane society depends upon the availability of enough food, clean water, fresh air, and space for all. People find it hard to behave humanely when they are hungry, thirsty, sick, or crowded. A comfortable physical environment helps people treat one another humanely. Nurturing the natural environment is also an important component of creating and maintaining a humane society. Care for the environment must include a spirit of frugality. Taking from the environment only what is need, using what is taken wisely, not wasting or polluting, and protecting fragile ecosystems help to build a humane society. Benedict and Francis both wrote extensively on the proper amount of food, drink, and creature comforts their followers should receive, but they also admonished their followers to cherish those re- sources without fetishizing them. Care for the environment must include an attitude of stewardship. Taking from the environment only what is needed and protecting or restoring fragile ecosystems help to build a humane society that can be sustained into the future.

Deferring to the needs of others. Confucius posits that deferring to the needs of others helps to bring about a humane society. Benedict and Francis require this deference from their followers. Within monastic communities, peace cannot be maintained if each community member thinks only of his or her own needs. If everyone defers to the needs of others, the humane society becomes a reality. Each person could have the comfort of knowing that he or she would always be safe and cared for. This sense of personal security might help the person dare to serve others, creating a chain of positive events that brings about the humane society.

For those who dare to hope that a more humane society is possible, Confucius, Benedict of Nursia and Francis of Assisi have developed actions plans that have been tested for centuries. Confucius' teachings have been widely studied seriously in Eastern cultures for millennia. In the West, countless people have embraced either Benedict's Rule or Francis' Rule and have dedicated their lives to living according to them. Even more people have benefitted from the work of Confucian scholars, vowed and oblate Benedictines, and active and contemplative Franciscans who have dared to dream of a more humane world and then dedicated their lives to making the dream a reality.

\section{REFERENCES}

[1] F. Karakas and E. Sarigollu, "The Role of Leadership in Creating Virtuous and Compassionate Organizations: Narratives of Benevolent Leadership in an Anatolian Tiger," Journal of Business Ethics, Vol. 113, No. 4, 2013, pp. 663-678. doi:10.1007/s10551-013-1691-5

[2] D. Liu, H. Liao and R. Loi, “The Dark Side of Leadership: A Three-Level Investigation of the Cascading Effect of Abusive Supervision on Employee Creativity,” Academy of Management Journal, Vol. 55, No. 5, 2012, pp. 11871212. doi: $10.5465 / \mathrm{amj} .2010 .0400$

[3] D. Mayer, K. Aquino, R. Greenbaum and M. Kuenzi, "Who Displays Ethical Leadership, and Why Does It Matter? An Examination of Antecedents and Consequences of Ethical Behavior," Academy of Management Journal, Vol. 55, No. 1, 2012, pp. 151-171. doi:10.5465/amj.2008.0276

[4] E. McLean, E. Burris and J. Detert, "When Does Voice Lead to Exit? It Depends on Leadership," Academy of Management Journal, Vol. 56, No. 2, 2013, pp. 525-548. doi:10.5465/amj.2011.0041

[5] D. Parris and J. Peachey, "A Systematic Literature Review of Servant Leadership Theory in Organization Contexts,” Journal of Business Ethics, Vol. 113, No. 3, 2013, 
pp. 377-393. doi:10.1007/s10551-012-1322-6

[6] C. Caldwell, R. Dixon, L. Floyd, J. Chaudoin, J. Post and G. Cheokas, "Transformative Leadership: Achieving Unparalleled Excellence,” Journal of Business Ethics, Vol. 109, No. 2, 2012, pp. 175-187. doi:10.1007/s10551-011-1116-2

[7] J. Ishikawa, "Transformational Leadership and Gatekeeping Leadership: The Roles of Norm for Maintaining Consensus and Shared Leadership in Team Performance," Asia Pacific Journal of Management, Vol. 29, No. 2, 2012, pp. 265-283. doi:10.1007/s10490-012-9282-z

[8] H. Al-Sharafi and I. Rajiani, "Promoting Organizational Citizenship Behavior among Employees: The Role of Leadership Practices,” Journal of Business and Management, Vol. 8, No. 6, 2013, pp. 47-54.

[9] A. Grant, "Leading with Meaning: Beneficiary Contact, Prosocial Impact, and the Performance Effects of Transformational Leadership," Academy of Management Journal, Vol. 55, No. 2, 2012, pp. 458-476. doi:10.5465/amj.2010.0588

[10] A. Sadeghi and Z. Pihie, "Transformational Leadership and Its Predictive Effects of Leadership Effectiveness," International Journal of Business and Social Sciences, Vol. 3, No. 7, 2012, pp. 186-197.

[11] S. Du, V. Swaen, A. Lindgreen and S. Sen, "The Roles of Leadership Styles in Corporate Social Responsibility," Journal of Business Ethics, Vol. 114, No. 1, 2013, pp. 115-169. doi:10.1007/s10551-012-1333-3

[12] L. Metcalf and S. Benn, "Leadership for Sustainability: An Evolution of Leadership Ability,” Journal of Business Ethics, Vol. 112, No. 3, 2013, pp. 369-384. doi:10.1007/s10551-012-1278-6

[13] J. Schaubroeck, S. Hannah, B. Avolio, S. Kozlowski, R. Lord, L. Trevino, N. Dimotakis and A. Peng, "Embedding Ethical Leadership within and across Organization Levels,” Academy of Management Journal, Vol. 55, No. 5, 2012, pp. 1053-1078. doi:10.5465/amj.2011.0064

[14] B. Schyns, T. Kiefer, R. Kerschreiter and J. Tymon, “Teaching Implicit Leadership Theories to Develop Leaders and Leadership: How and Why It Matters,” Academy of Management Learning and Education, Vol. 10, No. 3, 2011, pp. 397-408. doi:10.5465/amle.2010.0015

[15] H. Eghdamy, “Transformative Leadership,” Interdisciplinary Journal of Contemporary Research in Business, Vol. 4, No. 9, 2013, pp. 93-98.

[16] A. Salcer, G. Goodman and P. Decker, "Fostering Transformational Leadership in Business and Health Administration Education through Appreciative Inquiry," Business Education Innovation Journal, Vol. 4, No. 2, 2012, pp. 10-19.

[17] C. Sarwar, "Future of Ethically Effective Leadership," Journal of Business Ethics, Vol. 113, No. 1, 2013, pp. 8189. doi:10.1007/s10551-012-1283-9

[18] L. Palazzolo and L. Norton, "Evolving Leadership for an Awakening World: Transforming Leadership through Theory, Action, and Application,” Integral Leadership Re- view, 2012.

[19] J. Ching, “Confucianism and Christianity,” Kodansha International, Tokyo, 1977.

[20] T. Cleary, "The Essential Confucius. The Heart of Confucius' Teachings in Authentic I Ching Order," HarperCollins, New York, 1992.

[21] Confucius (n.d.). http://www.humanistictexts.org/confucius.htm

[22] R. Dawson, “Confucius,” Oxford University Press, London, 1981.

[23] D. Hall and R. Ames, "Thinking through Confucius," State University of New York Press, Albany, 1987.

[24] D. Hinton, “The Analects. Confucius,” Counterpoint, Washington DC, 1998.

[25] S. Kaizuka, “Confucius,” C. Tinling and Company, Liverpool, 1956.

[26] Y. Lin, "The Wisdom of Confucius," Random House, New York, 1938.

[27] M. Nylan and T. Wilson, "Lives of Confucius: Civilization's Greatest Sage through the Ages," Doubleday Religion, New York, 2010.

[28] W. Soothil, “The Analects,” Oxford University Press, London, 1962.

[29] B. Watson, "The Analects of Confucius," Columbia University Press, New York, 2007.

[30] P. Zukeran, “Confucius,” 2011. http://leaderu.com/org/probe/docs/confucius.html

[31] M. Goberna, "The Rule of St. Benedict for Everyone," New City Press, Hyde Park, 2010.

[32] T. Kardong, "The Life of St. Benedict by Gregory the Great,” Liturgical Press, Collegeville, 2009.

[33] R. Benson, “A Good Neighbor: Benedict's Guide to Community,” Paraclete Press, Brewster, 2009.

[34] A. Bockmann, "Around the Monastic Table-RB 31-42. Growing in Mutual Service and Love,” Liturgical Press, Collegeville, 2009.

[35] M. Casey, "Strangers to the City. Reflections on the Beliefs and Values of the Rule of St. Benedict," Paraclete Press, Brewster, 2005.

[36] A. De Vogue, "Community and Abbot in the Rule of St. Benedict,” Cistercian Publications, Kalamazoo, 1978.

[37] E. De Waal, "Seeking Life. The Baptismal Invitation of the Rule of St. Benedict,” Liturgical Press, Collegeville, 2009.

[38] A. Grun, "Benedict of Nursia. His Message for Today," Liturgical Press, Collegeville, 2006.

[39] B. Hume, "In Praise of Benedict,” Saint Bede’s Publications, Petersham, 1981.

[40] S. Kleiner, "Serving God. Insights on the Rule of St. Benedict,” Cistercian Publications, Kalamazoo, 1985.

[41] D. Parry, "Households of God. The Rule of St. Benedict, with Explanations for Monks and Lay-People Today," Cistercian Publications, Kalamazoo, 1980.

[42] A. Wathen, "Silence. The Meaning of Silence in the Rule 
of St. Benedict,” Cistercian Publications, Washington, 1973.

[43] A. House, "Francis of Assisi. A Revolutionary Life," Hidden Spring, Mahwah, 2001.

[44] G. Chesterton, "St. Francis of Assisi," Hodder \& Stoughton, London, 1923.

[45] R. Armstrong and I. Peterson, "The Franciscan Tradition. Spirituality in Action,” The Liturgical Press, Collegeville, 2010.

[46] G. Chesterton, "Francis of Assisi on Nature,” In: L. Cunningham, Ed., Brother Francis: An Anthology of Writings by and about St. Francis of Assisi, Harper \& Row, New York, 1972.

[47] M. Crosby, "Finding Francis, Following Christ," Orbis Books, Maryknoll, 2007.

[48] J. Green, "God's Fool: The Life and Times of Francis of Assisi,” Harper \& Row, New York, 1983.

[49] K. Knight, "Francis of Assisi," Catholic Encyclopedia, 2009. http://www.newadvent.org/cathen/06221a.htm

[50] A. Masseron, “The Franciscans,” Franciscan Herald Press, Chicago, 1959.

[51] J. Roddy, "Francis of Assisi: The Hippie Saint,” In: L. Cunningham, Ed., Brother Francis: An Anthology of
Writings by and about St. Francis of Assisi, Harper \& Row, New York, 1972, pp. 43-52.

[52] P. Sabbatier, "Vie de Saint Francois D’Assise (Translated)," In: L. Cunningham, Ed., Brother Francis: An Anthology of Writings by and about St. Francis of Assisi, Harper \& Row, New York, 1972, pp. 16-25.

[53] W. Short, "Poverty and Joy. The Franciscan Tradition," Orbis Books, Maryknoll, 1999.

[54] F. Heer, "St. Francis: The Medieval Man and His Culture,” In: L. Cunningham, Ed., Brother Francis: An Anthology of Writings by and about St. Francis of Assisi, Harper \& Row, New York, 1972, pp. 108-124.

[55] Francis of Assisi (n.d.-a), “Canticle of the Sun,” 2011. http://webster.edu/ barrettb/canticle.htm

[56] Francis of Assisi (n.d.-b), "Prayer of St. Francis of Assisi (Peace Prayer)," 2011.

http://www.catholicnewsagency.com/resources/saints/sain ts/peace-prayer-of-st-francis-of-assisi/

[57] T. Fry, “The Rule of St. Benedict in English,” Liturgical Press, Collegeville, 1982.

[58] Francis of Assisi (n.d.-c), "Rule of the Franciscan Order," 2011. http://www.shrinesf.org/francis12.htm

[59] “Holy Bible,” Liturgical Press, Collegeville, 1993. 